\title{
Social Capital and Political Participation: A Case Study from Rural Bangladesh
}

\author{
Md Masud Sarker ${ }^{1}$ \\ Md. Shahidul Islam ${ }^{2}$ \\ ${ }^{I}$ Associate Professor, Department of Political Studies, Shahjalal University of Science and Technology, \\ Bangladesh \\ ${ }^{2}$ Senior Assistant Secretary, Research and Development $(R \& D)$ Cell, Bangladesh Knitwear Manufacturers and \\ Exporters Association, and Adjunct Research Fellow, Bangladesh Institute of Social Research (BISR) Trust. \\ Bangladesh
}

(C) 2017Masud Sarker, Shahidul Islam

This is an open access article distributed under the Creative Commons Attribution-NonCommercial-NoDerivs license (http://creativecommons.org/licenses/by-nc-nd/3.0/)

DOI: $10.1515 /$ eras-2017-0009

\begin{abstract}
Social capital supports toward participating in political activities in democratic countries. This study tries to examine the relation between social capital and political participation in Bangladesh. A cross-sectional study was conducted in Sylhet Sadar Upazila (sub-district) of north-eastern Bangladesh. A total of 100 respondents who are above 23 years of age - were selected by using systematic random sampling technique for a face-to-face interview. Chi-square test and Fisher Exact test were applied to measure the association between social capital dimensions and political participation. The results show that social networks, civic participation, norms of reciprocity and social trusts are significantly associated with political participation in Bangladesh. This result suggests that social capital may have an effect towards an increment of a political participation in Bangladesh.
\end{abstract}

Keywords:Social capital, Political participation, Civic engagement, Bangladesh

\section{INTRODUCTION}

Bangladesh became an independent country in 1971 after the nine-month war of liberation with Pakistan. Although Bangladesh has some experience with military rules, politics in Bangladesh has already taken place in the parliamentary system where a multiparty system exists. Local government system also exists where its representatives are directly elected by the people. Democratic values have always been a great appeal for Bangladesh citizens. For this reason, democratic political system has been inspired by democratic ideals (Ahmed, 2015)

In Bangladesh, eligible citizens can directly or indirectly participate in politics. At nominal level, political participation is considered as voting in election or opting out of this option. But in a broader sense, a political participation includes a vote, a political or non political campaign, and a contact with decision-makers or civic engagement for any kinds of influences, and cooperation with others. There are two types of political participation, institutional and non-institutional (Suh, 2013). Institutional political participation is directly related to elect an official through participation in vote, political rallies, and joining parties. Non-institutional participation indirectly influences political process including signing petitions, boycotts, and demonstrations (Suh, 2013). Political participation can be considered as the action of a private citizen that aspires to influence the government policy or support government and politics. It is also considered as "all voluntary activities by individual citizens intended to influence either directly or indirectly political choices at various levels of 
the political system" (Milbrath and Goel, 1977:2). Political participation is the action by common citizens for influencing some political outcomes. This action can be taken to influence other including powerful actors, groups, or business organization enterprises or trade bodies and their decision in many societal issues (Ekman and Amna, 2012).

In other words, political participation is the representativeness of the public support for government actions. Citizen's participation in both direct and indirect forms of political influences the government politics (Wagle, 2006). Casting vote in the election and electing political representative is the institutional forms of the citizen's that make and influence the public policy. The election can be considered the legitimate action of both the legislative and executive branches of government. People's participation in un-institutional structures, including voluntary and involuntary engagement forms of political participation as rallies, dispute, demonstrations, and meetings, donation of money or collection money to candidates or political causes, written or verbal communication with political leaders and obtaining their attention, discuss about politics in the internet, participated in civic/ local resident movement, signed a petition are also part of political participation these indirectly influence the public policy. People's political participation can vary not only for their demographic, socioeconomic characteristics but also for their interests, choices, and preferences (Wagle, 2006).

Recently, there rising consciousness that social capital is positively associated with the social, economic and ecological wellbeing. Social relation is the sources of a civic participation and this civic participation enhances the political participation. Membership of an association or civil society organization influences the one person towards actively political participation (Suh,2013). Social capital is the formal and informal social relation that based on trust and reciprocity (Sarker and Islam, 2014). This social relation enhances the citizens' capacity to influence the government to address their problems. People who have membership in a local community group can influence the local government to develop their community development. According to Putnam, social capital increases the democratic performance of institutions (Lowndes, 2004). As social capital increases the civic virtue, lack of it will increase the lack of political participation as well as political dissatisfaction. Social trust is closely related to political participation because it increases the level of depth of interaction and increases the cooperation of people in the process of communication. People who are actively participated in the voluntary activities are more likely to participate in politics. That organizational involvement has created "weak ties' in a social relationship thereby increase the participation in politics (Teorell, 2003). There are some studies in Bangladesh that focus on the perception of political participation and their socio economic characteristics of the participants. But the link of social capital and political participation is missing among the studies. In Bangladesh rural area, kinship network also affects the process of political involvement. Social capital provides both glue and gear to political participation (Krishna, 2002). But there is no parameter in Bangladesh that measures the impact of social capital in political participation in Bangladesh. The aim of this study is to understand the relation between social capital and political participation in Bangladesh. This study may also help to political leader, political party to create social capital among them because it not only influences the voting behaviour in local or national level election but also it increases the severity of the political participation. This paper also helps to government to create social trust between the government and citizens as its increase the performances of the government. 


\subsection{THE CONCEPT OF SOCIAL CAPITAL}

Generally, interpersonal networks and social interactions are the core of social capital (Hassan and Birungi, 2011). Pierre Bourdieu defined social capital as: "the aggregate of the actual or potential resources that are linked to possession of a durable network of more or less institutionalized relationships of mutual acquaintance and recognition... which provides each of its members with the backing of collectively-owned capital" (Bourdieu, 1997: 51). According to Putnam, social networks are valuable for an individual. It enhances the outcomes of individuals and groups. Social capital arises from the social relationship that depends on social networks, norms of reciprocity and trustworthiness (Häuberer, 2011). Putnam (1995) defined social capital as "features of social organization, such as trust, norms and networks that can improve the efficiency of society by facilitating coordinated actions" (1995: 167). Putnam's social capital related to relationship of people and political participation (Häuberer, 2011). He distinguished between social capital and political participation. According to him, social capital is a relationship within one another and political participation is the relationship with political institutions.

There are three types of social capital: bonding, bridging and linking. Bonding social capital includes horizontal ties and social interaction within a homogenous group. It is the strong ties among close friends or immediate family members with similar interests (Ellison et al., 2007) or with similar social characteristics such as neighbours, social class, colleague or religion, same racial or ethnic group, and voluntary associations. Bridging social capital means forging vertical ties and connection in heterogeneous group with different social characteristics. This is the weak ties that link different formal and informal social participation, like as loose friendships and workmates, membership with voluntary association with different backgrounds (Derso and Varda, 2007). Linking social capital is the relation between individuals and different groups (Cote and Healy, 2001. It includes various social ties and resources that are found between a community, neighbourhood and institutions or individuals ability to access to resources outside of his community (Derso and Varda, 2007).

\subsection{SOCIAL CAPITAL AND POLITICAL PARTICIPATION:}

Nygård et al. (2015) investigated the role of social capital in political participants of older adult in Finland and Sweden. They found that membership in voluntary associations, dense social networks and high levels of interpersonal trust are positively correlated with different level of political participation. Shuh (2013) examined the relationship between social capital and political participation in 48 countries. He also demonstrated the relationship between social capital and other macro variables on economic political development, economic inequality, and political participation in these countries. They revealed that general trust, civic participation, and confidence in government influenced the political participation. Their study also reveals that economic political development and economic inequality also modifies the relationship between social capital and political participation

Kuenzi (2008) identified the variables that influence the political trust and social capital in Nigeria and Ghana. They found that trust in political institutions is the major determinants of interpersonal trust in Ghana. They also found that education, age and ethnicity were positively affected by the social capital and political trust, but there was a negative relationship between education and interpersonal trust. Teney and Hanquinet (2012) examined the relationship between social capital and political participation in Brussels, Belgium. They found that the 'Committed Class' are based on a diversified society with high socio- economic background are involving in a large diversity of political activities. They also revealed that religious class- based social capital have specific effects on political 
participation. McClurg (2003) found that social networks/ interactions have positively influenced in political participation. Social interaction increases the accessibility of the information about political activity and it also reduces the resource (information) constraints. Kim (2005) examined the relationship between social capital and political trust in South Korea. He found that social capital did not significantly associate with civic participation in institutional politics in the country. He also reveals that social trust and associational involvement were negatively influenced in trust in political institution, even that have no impact on increasing the commitment of voting. Farris and Holman (2014) examined the role of social capital in political participation of the black women in America. They found that social capital is the key factor to political participation of the black women. They reveal that by using social capital, black women have the higher participation in politics than other groups. Skoric et al. (2009) examined the role of internet based social capital on both online and traditional political participation in Singapore. Their study also revealed that online bridging social capital is associated with the both traditional and online political participation. Demirhan (2012) investigated the relationship between social capital and political participation in terms of politics in the new globalization perspective. He argued that social relations and social networks enhance the social action that promotes social participation. $\mathrm{He}$ mentioned that in new globalization period there is rising importance of increasing importance of communication and social interactions for political participation. La Due Lake and Huckfeldt (1998) examined the interrelation among social capital, social network and political participation. They found that social capital enhanced the probability of a citizen's participation in politics. Their study also revealed that people who have large social network are more likely to engage in a political campaign. Lowndes (2004) explained the gender difference in social capital in political engagement. They found that women are less likely to use their social capital in formal political participation compared to men.

\section{DATA AND METHODS}

\subsection{PARTICIPANTS}

Both primary and secondary data were used in this study. Primary data was collected from a rural area of north-eastern Bangladesh. Data was collected from Tuker Bazar Union Parishad (UP) (the lowest tier of local government) under Sylhet Sadar Upazila . Systematic random sampling method was used to select the study area as well as respondents selection. From the study area, a UP ward was selected and then the respondents were selected from the household. One respondent is only selected from one household. A total of 100 respondents were from each household selected for the study. Although an age of 18 years is required to become a voter, in Bangladesh, we have selected the respondents (male or female) above 23 years of age for this study. In this study, $10 \%$ margin of error was considered in this study. Where the $t$ value for selected alpha level of .025 in each tail was 1.96 , and non response rate of the study is $10 \%$. The interval of one household to another household is 22 .

\subsection{DATA COLLECTION}

Semi-structure questionnaire was used for primary data collection. The questionnaire has three sections as: (1) Background information of the respondents; (2) social capital; and (3) political participants. 


\subsection{DATA ANALYSIS}

Collected data was analysed by using SPSS (Statistical Package for Social Sciences) version 23. Frequency distribution and cross-tabulation were used to analyse the data. Chisquare test $\left(\chi^{2}\right)$ and Fisher Exact test were applied to check the association between social capital dimensions and political participation.

\subsection{VARIABLE OF THE STUDY}

\subsubsection{INDEPENDENT VARIABLES}

Social capital is considered as the independent variable. Social capital is a multidimensional concept and cannot be measured with a single indicator. In our study, social capital was measured by using six dimensions including social networks, general social trust, norms of reciprocity, neighbourhood social cohesion, social support, and civic engagement (Islam and Alam, 2013). This social capital indicators, dimensions and measurement method was adopted from Islam and Alam's(2013) method.

\subsubsection{DEPENDENT VARIABLE}

The political participation was measured by using 16 questions combined of both institutional and non institutional political and creating an index by these variables both. To create the index of political participation, we gave the value 1 for "yes" response, and 0 for "no response". The index score ranges from 0 to 16 that denote the lowest to highest level of political participation. For example, if a respondent answered "yes" for all the 16 questions, then index score will be 16, meaning that this person has highest level of political participation. If a respondent answered "no" to all the 16 questions, so his/her political participation score will be 0 , indicating that the person has lowest level of political participation. For the score between 0and 8, we assumed that the respondent has low level of political participation, and for the score between 9 and 16, we assumed that the respondent has high level of political participation.

\subsection{RELIABILITY}

To check the internal consistency reliability of the social capital dimensions, Cronbach's alpha was applied. Here, the internal consistency reliability of the neighbourhood cohesion, social network, and trust were found 0.903, 0.913, and 0.910 these are excellent. The value of the Cronbach's alpha of the norms of reciprocity was 0.923 which was excellent. The internal consistency reliability of the social support and civic engagement are 0.825 and 0.812 which indicates the good internal consistency reliability. 


\section{RESULTS}

TABLE 1. DEMOGRAPHIC CHARACTERISTIC

\begin{tabular}{|l|l|l|}
\hline Sex of the respondents & Frequency & Percent \\
\hline Male & 79 & 79.0 \\
\hline Female & 21 & 21.0 \\
\hline Total & 100 & 100.0 \\
\hline Age of the respondents & & \\
\hline $23-30$ & 48 & 48.0 \\
\hline $31-40$ & 24 & 24.0 \\
\hline $41-50$ & 10 & 10.0 \\
\hline $51-60$ and above & 18 & 18.0 \\
\hline Total & 100 & 100.0 \\
\hline Educational qualification & & \\
\hline Illiterate & 16 & 16.0 \\
\hline Primary & 15 & 15.0 \\
\hline Secondary & 29 & 29.0 \\
\hline Higher secondary and above & 40 & 40.0 \\
\hline Total & 100 & 100.0 \\
\hline Religion of the respondents & & \\
\hline Muslims & 89 & 89.0 \\
\hline Hindus & 11 & 11.0 \\
\hline Total & 100 & 100.0 \\
\hline
\end{tabular}

\subsection{BACKGROUND INFORMATION}

Majority $(79.0 \%)$ of the respondents are male and only $21 \%$ respondents are female. According to age, about $48.0 \%$ respondents' age is between 25 to 30 years, $24 \%$ respondents age are between 31 to 40 years, $10 \%$ respondents age are between 41 to 50 years, and $18 \%$ respondent belongs to age group 51-60 and above group. According to educational qualification, the highest $40 \%$ respondents have completed higher secondary and above, $29.0 \%$ respondent completed secondary and $16 \%$ respondents are illiterate. From the same table it is clear that majority of the respondents (89\%) are Muslim and only $11 \%$ respondents are Hindus.

\subsection{LEVEL OF POLITICAL PARTICIPATION}

TABLE 2. POLITICAL PARTICIPATION OF THE RESPONDENTS (INSTITUTIONAL AND NONINSTITUTIONAL)

\begin{tabular}{|l|l|l|}
\hline Indicator of political participation & Yes $(\%)$ & $\mathrm{No}(\%)$ \\
\hline Voted in last parliamentary, or local government election & 84.0 & 16.0 \\
\hline Contacted a local influential person & 39.0 & 61.0 \\
\hline $\begin{array}{l}\text { Contacted a politician, administration or government or } \\
\text { local government official }\end{array}$ & 22.0 & 78.0 \\
\hline effort in a political party or action group & 14.0 & 86.0 \\
\hline Participated an assembly or public office to petition or lobby & 13.0 & 87.0 \\
\hline
\end{tabular}




\begin{tabular}{|l|l|l|}
\hline Went to in assemblies pertaining to an election or politics & 17.0 & 83.0 \\
\hline $\begin{array}{l}\text { Helped in an election campaign (such as supporting a } \\
\text { candidate or to a particular party) }\end{array}$ & 10.0 & 90.0 \\
\hline Participated in the election rallies and street oratories & 15.0 & 85.0 \\
\hline Member of any political party & 16.0 & 84.0 \\
\hline $\begin{array}{l}\text { Persuaded others to vote for a particular candidate or } \\
\text { candidate of political party }\end{array}$ & 22.0 & 78.0 \\
\hline Participated in civic/ local resident movement & 16.0 & 84.0 \\
\hline Signed a petition & 16.0 & 84.0 \\
\hline Participated in fund-raising or made donation & 16.0 & 84.0 \\
\hline Participated in a demonstration & 10.0 & 90.0 \\
\hline Discussed about politics in the internet & 26.0 & 74.0 \\
\hline Boycotted products/ party/ election & 23.0 & 77.0 \\
\hline
\end{tabular}

Source: Adopted from: Inamasu and Ikeda, 2008; Bäck and Christensen, 2011;Suh,2013).

The study found that majority $(84.0 \%)$ of the respondents casted their vote to at least one of the last national parliamentary and/or local government election. $39.0 \%$ of the respondents contacted a local influential person for their personal and political issues. Only $22.0 \%$ respondents reported that they contacted a politician, government or local government official. Only $14.0 \%$ respondents actively worked in a political party or action group. Only $13.0 \%$ respondents participated in an assembly or public office to petition or lobby. Only $17.0 \%$ respondents went to in assemblies pertaining to an election or politics. Only $10 \%$ respondents helped in an election campaign for supporting a candidate or to a particular party. Only $15 \%$ respondents participate in the election rallies and street oratories. $16.0 \%$ respondents are member of a political party. Only $22 \%$ respondents persuade others in the last local government or parliamentary election to vote for a particular candidate or candidate of political party. $16 \%$. 0 respondents participated in civic or local resident movement. $16.0 \%$ respondents signed in any petition. $16 \%$ respondents working for fund raising for their political party or made donation for the political party. $26.0 \%$ respondents discuss political matter in internet and $23.0 \%$ respondents boycotted any product or election (Table 2).

\section{BIVARIATE ANALYSIS:}

TABLE 2. RELATIONSHIP BETWEEN SOCIAL CAPITAL DIMENSIONS AND POLITICAL PARTICIPATION

\begin{tabular}{|c|c|c|c|c|c|c|}
\hline \multirow[t]{3}{*}{ Variable } & \multicolumn{4}{|c|}{ Political participation } & \multicolumn{2}{|c|}{ Total } \\
\hline & \multicolumn{2}{|c|}{ Low } & \multicolumn{2}{|c|}{ High } & \multirow{2}{*}{$\mathrm{n}$} & \multirow[b]{2}{*}{$\%$} \\
\hline & $\mathrm{n}$ & $\%$ & $\mathrm{n}$ & $\%$ & & \\
\hline \multicolumn{7}{|c|}{ Social networks } \\
\hline Low & 40 & 88.9 & 5 & 11.1 & 45 & 100 \\
\hline High & 37 & 67.3 & 18 & 32.7 & 55 & 100 \\
\hline Total & 77 & 77.0 & 23 & 23.0 & 100 & 100 \\
\hline \multicolumn{7}{|c|}{$\chi^{2}=923, \mathrm{df}=1, \mathrm{P}=0.011$} \\
\hline \multicolumn{7}{|c|}{ Norms of reciprocity } \\
\hline Low & 37 & 88.1 & 5 & 11.9 & 42 & 100.0 \\
\hline High & 40 & 69.0 & 18 & 31.0 & 58 & 100.0 \\
\hline
\end{tabular}




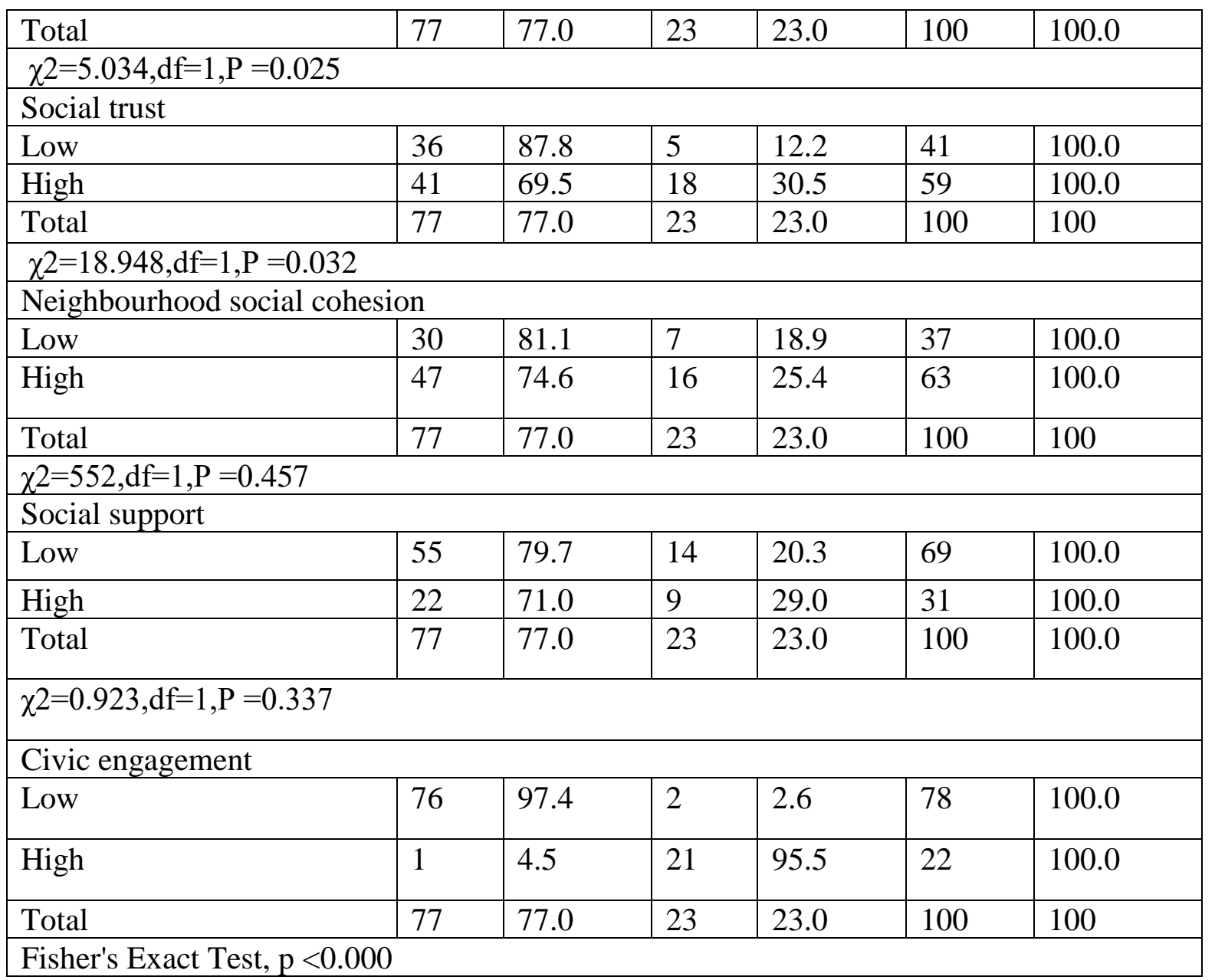

Social networks increases the political participation of respondents. The table shows that political participation is higher $(32.7 \%)$ in respondents who have high social network compared to who have low social network. The $\chi 2$ test also shows that the association between social networks and political participation is significant (Table 2).

Higher level of norms of reciprocity also increases the political participation. The table shows that $11.9 \%$ respondent have higher level of political participation who have high norms of reciprocity. $31.0 \%$ respondents have higher level of political participation whose have low norms of reciprocity. So, political participation increases with the increases of norms of reciprocity. The $\chi 2$ test also shows that there is a significant association between norms of reciprocity and political participation (Table 2 ).

Social trust is positively associated with political participation. The table shows that political participation are higher $(30.5 \%)$ among the respondents who have high social trust. Reversely, political participation is lower $(12.2 \%)$ among the respondents who have low social trust. The $\chi 2$ test also shows the association between social trust and political participation is significant (Table 2).

Respondents who have high neighboured social cohesion are more likely to participate in politics. The table shows that only $(18.9 \%)$ respondents who have low neighbourhood social cohesion. have higher level of political participation. But $25.4 \%$ respondents have high political participation and have high neighboured social cohesion. But $\chi^{2}$ test also shows that there is no significant association between neighboured social cohesion and political participation (Table 2).

Social support also increases the political participation of the respondents. Only 
(20.3\%) respondents have high political participation whose have low social support. But the rate of higher political participation is $(29.0 \%)$ among the respondents who have high social support. But $\chi 2$ test also shows that there is no significant association between social support and political participation (Table 2).

Civic engagement is a crucial factor to political participation. The table shows that high political participation is considerably lower (2.6\%) among respondents people who have low civic engagement while high political participation is considerably higher (95.5\%) among the respondents who have high civic engagement. So, political participation increases with the increases of civic engagement. The Fisher's Exact Test also shows that the association between civic engagement and political participation status is significant (Table 2).

\section{DISCUSSION AND CONCLUSION}

This study reveals that civic engagement is strongly associated with political participation in Bangladesh. Civic engagement or engagement in community organization and formal political participation mutually reinforces one another. Engagement in social and protest movement in community level, grassroots level of civic organization and trade union increases the formal political participation (Pahad, 2005). Additionally, people get organized themselves to solve local problems and to improve the condition of certain group or society (Ekman and Amnå, 2012).

Social networks also increase the political participation of the citizens. It also represents the intensity of activeness of actor in their social interactions. Peoples' individual perception is also influenced by their social networks. Social network have different nature, content, and function that influence the intensity of institutional and non- institutional political participation of an actor.

Social trust is the fabric of social life and enhances cooperative social relation that builds effective social and political organizations (Bäck and Christensen, 2016). Social trust at the societal level increases the social cohesion that helps citizens to come together to join in social and political networks. It is the moral based resources that cooperate to actor participation in politics. But Kim (2005) study show that social trust is negatively associated in political institutions. Even, social trust does not increase the commitment of voting in South Korea. He also revealed that social trust has no impact on politics where political corruption is high and low institutional performances.

Our study also reveals that community level neighbourhood social cohesion and social support are not significant and result in high political participation. A study by Kim (2005) showed the similar result in South Korea that community level citizen's attachment and collaboration for social benefit do not increase the political participation.

\section{LIMITATIONS}

The sample size of this study is small. To understand the better result, large-scale sample will be required. Higher level of social capital will increase the higher level of political participation or higher level of political participant has higher level of social capital. But our study only reveals the association between social capital and political participation. Further research needs to address the causal relation between the social capital and political participation as well as their direction. Several individual- level factor as education, gender, family backgrounds, political awareness also influence on political participation, but this study has only covered the link between social capital and political participation. 


\section{REFERENCES}

Ahamed, Emajuddin (2015, 27 October,): Democracy in Bangladesh: Prospects and Problems, Daily Sun. Retrieved from http://www.daily-sun.com/arcprint/details/86261/Democracy-in-Bangladesh:-Prospectsand-Problems/2015-10-27.

Bäck, M., \& Christensen, H. S. (2011). Social trust and Political Participation-A multilevel analysis of 25 European democracies. Working paper.

Bourdieu, P. (1986). The forms of capital. In J. G. Richardson (Ed.), Handbook of theory and research forthe sociology of education (pp. 241-258). New York: Greenwood.

Brady, H. E. (1999). Political participation. Measures of political attitudes, 2, 737-801.

Côté, S., \& Healy, T. (2001). The well-being of nations: The role of human and social capital. Paris: Organisation for Economic Co-operation and Development.

Demirhan, K. (2012). Politics in the globalization: thinking on the relations between social capital and political participation write in correct case. International Journal of Social Sciences And Humanity Studies,4(1):229-238

Derose, K. P., \& Varda, D. M. (2009). Social capital and health care access: a systematic review.Medical Care Research and Review, 66(3): 272-306. doi:10.1177/1077558708330428.

Ekman, J., \&Amnå, E. (2012). Political participation and civic engagement: Towards a new typology.Human affairs, 22(3), 283-300.

Ellison, N. B., Steinfield, C., \& Lampe, C. (2007). The benefits of Facebook "friends:" Social capital and college students' use of online social network sites. Journal of Computer-Mediated Communication, 12(4), 1143-1168.

Farris, E. M., \& Holman, M. R. (2014). Social capital and solving the puzzle of Black women's political participation. Politics, Groups, and Identities, 2(3), 331-349.

Hassan, R., \& Birungi, P. (2011). Social capital and poverty in Uganda. Development Southern Africa, 28(1), 19-37.

Häuberer, J. (2010).Social capital theory: Towards a methodological foundation. Springer Science \& Business Media.

Inamasu, K., \& Ikeda, K. I. (2008). The effect of gendered social capital on political participation: Using the Position Generator method on the JES3 Dataset. In a conference on social capital held at Academia Sinica, Taipei, Taiwan.

Islam, M. S., \& Alam, M. S. (2014). Social Capital and Mental Health: Results from a Cross-Sectional Study in Bangladesh. Asian Social Science, 10(2), 118.

Iisakka, L., (2006). Social capital and trust. Social Capital in Finland: Statistical Review. Statistics Finland, Helsinki,.23-32.

Kim, J. Y. (2005). "Bowling together” isn'ta cure-all: The relationship between social capital and political trust in South Korea. International Political Science Review, 26(2), 193-213.

Krishna, A. (2002). Enhancing political participation in democracies: what is the role of social capital? Comparative Political Studies, 35(4), 437-460.

Kuenzi, M. T. (2008). Social capital and political trust in West Africa. Afro barometer Working paper, 96, 1-32.

La Due Lake, R., \&Huckfeldt, R. (1998). Social capital, social networks, and political participation. Political Psychology, 19(3), 567-584.

Lowndes, V. (2004). Getting on or getting by? Women, social capital and political participation. The British Journal of Politics and International Relations, 6(1), 45-64.

McClurg, S. D. (2003). Social networks and political participation: The role of social interaction in explaining political participation. Political research quarterly, 56(4), 449-464.

Milbrath, L. W., La Goel, M. (1977). Political Participation. How and Why People Get Involved in Politics. Chicago: RandMcNally

Nygård, M., Nyqvist, F., Steenbeek, W., \&Jakobsson, G. (2015). Does social capital enhance political participation of older adults? A multi-level analysis of older Finns and Swedes. Journal of International and Comparative Social Policy, 31(3), 234-254.

Obst, P., Smith, S. G., \& Zinkiewicz, L. (2002). An exploration of sense of community, Part 3: Dimensions and predictors of psychological sense of community in geographical communities. Journal of community psychology, 30(1), 119-133.

Pahad, E. (2005). Political participation and civic engagement. Progressive Politics, 4(2), 24.

Putnam, R. D. (1995). Bowling alone: American civic engagement.A Progressive Journal of Democracy,6(1),6578

Sarker, M. M., \& Islam, M. S. (2014). Social Capital and Access to Microcredit: Evidence from Rural Bangladesh. Developing Country Studies, 4(7).55-61 
Skoric, M. M., Ying, D., \& Ng, Y. (2009). Bowling online, not alone: Online social capital and political participation in Singapore. Journal of Computer-Mediated Communication, 14(2), 414-433.

Sun, X., Rehnberg, C., \& Meng, Q. (2009). How are individual-level social capital and poverty associated with health equity? A study from two Chinese cities. International Journal for Equity in Health, 8(1), 2.

Suh, H.(2013). Correlation between Social Capital and Political Participation: Considering National Economic, Political Development, and Economic Inequality.

Teney, C., \& Hanquinet, L. (2012). High political participation, high social capital? A relational analysis of youth social capital and political participation. Social science research, 41(5), 1213-1226.

Teorell, J. (2003). Linking social capital to political participation: Voluntary associations and networks of recruitment in Sweden. Scandinavian Political Studies, 26(1), 49-66.

Wagle, U. R. (2006). Political participation and civic engagement in Kathmandu: an empirical analysis with structural equations. International Political Science Review, 27(3), 301-322. 